\title{
DEK-NUP214-Fusion Identified by RNA-Sequencing of an Acute Myeloid Leukemia with $\mathbf{t}(9 ; 12)(\mathbf{q 3 4} ; \mathbf{q 1 5})$
}

\author{
IOANNIS PANAGOPOULOS ${ }^{1}$, LUDMILA GORUNOVA ${ }^{1}$, SYNNE TORKILDSEN ${ }^{1,2}$, \\ GEIR E. TJØNNFJORD ${ }^{2,3}$, FRANCESCA MICCI ${ }^{1}$ and SVERRE HEIM ${ }^{1,3}$ \\ ${ }^{1}$ Section for Cancer Cytogenetics, Institute for Cancer Genetics and Informatics, \\ The Norwegian Radium Hospital, Oslo University Hospital, Oslo, Norway; \\ ${ }^{2}$ Department of Haematology, Oslo University Hospital, Oslo, Norway; \\ ${ }^{3}$ Institute of Clinical Medicine, Faculty of Medicine, University of Oslo, Oslo, Norway
}

\begin{abstract}
Background/Aim: Given the diagnostic, prognostic, biologic, and even therapeutic impact of leukemia-associated translocations and fusion genes, it is important to detect cryptic genomic rearrangements that may exist in hematological malignancies. Case Report: RNAsequencing was performed on an acute myeloid leukemia case with the bone marrow karyotype 45,X,-Y,t(9;12) (q34;q15)[16]. Results: The DEK-NUP214 and PRRC2B$D E K$ fusion genes were found. Reverse transcriptase polymerase chain reaction together with direct sequencing verified the presence of both. Fluorescence in situ hybridization showed that the DEK-NUP214 fusion gene was located on the $6 p 22$ band of a seemingly normal chromosome 6. Conclusion: RNA-sequencing proved to be a valuable tool for the detection of a fusion of genes DEK and NUP214 in a leukemia that showed cryptic cytogenetic rearrangement of chromosome band $9 q 34$.
\end{abstract}

Acquired genetic abnormalities are present in the leukemic bone marrow cells in hematologic $\alpha \lambda$ malignancies, including acute myeloid leukemia (AML) and acute lymphoblastic leukemia (ALL) (1-4). Microscopic studies have shown that these aberrations are often visible as balanced chromosomal changes such as translocations and inversions, as well as

This article is freely accessible online.

Correspondence to: Ioannis Panagopoulos, Section for Cancer Cytogenetics, Institute for Cancer Genetics and Informatics, The Norwegian Radium Hospital, Oslo University Hospital, Montebello, PO Box 4954 Nydalen, NO-0424 Oslo 0310, Norway. Tel: +47 22782363, e-mail: ioannis.panagopoulos@rr-research.no

Key Words: Acute myeloid leukemia, RNA-sequencing, $D E K$, NUP214, PRRC2B, DEK-NUP214 fusion gene, PRRC2B-DEK fusion gene. unbalanced anomalies such as deletions, monosomies, duplications, and trisomies (1). Leukemia-associated translocations and inversions often result in fusions at the breakpoints through melting together parts of two genes, one in each breakpoint. The chromosomal rearrangements giving rise to fusion genes are often seen as sole aberrations at cytogenetic analysis, are considered to be primary tumorigenic events, and are of pathogenetic, diagnostic, and prognostic importance (1).

Sometimes, cytogenetic analyses fail to detect chromosomal rearrangements because the regions involved are of similar size and have similar banding patterns, because of poor chromosome morphology and spreading, because too few metaphase cells could be analyzed, or only normal metaphases derived from non-leukemic cells are found after culturing. The application of molecular cytogenetic techniques such as fluorescence in situ hybridization (FISH), multicolor FISH, array comparative genome hybridization (aCGH), and singlenucleotide polymorphism (SNP) arrays may then be particularly valuable, alone or together with more exclusively molecular methods based on the polymerase chain reaction (PCR), and may improve significantly the rate at which genetic changes are found in hematological malignancies (5-12).

Not surprisingly, some chromosome aberrations and their corresponding fusion genes can be detected only with molecular methods. One of them is the $\mathrm{t}(12 ; 21)(\mathrm{p} 13 ; \mathrm{q} 22) /$ ETV6-RUNX1 which is one of the most common genetic rearrangements in pediatric B-lineage acute lymphoblastic leukemia (ALL) and defines a subgroup of patients with excellent prognosis $(13,14)$. Another example is the $\operatorname{del}(4)(\mathrm{q} 12 \mathrm{q} 12) / F I P 1 L 1-P D G F R A$ characteristic of hypereosinophilic syndrome. Patients with $\operatorname{del}(4)(q 12 q 12) / F I P 1 L 1-P D G F R A$ have an excellent prognosis when treated with imatinib (15-17).

Given the diagnostic, prognostic, biologic, and even therapeutic impact of leukemia-associated translocations and fusion genes, it is important to detect also cryptic genomic rearrangements that may be present in hematologic 
malignancies. High-throughput sequencing has been proven to be a powerful method for detecting fusion genes in cases with normal karyotype or with aberrations seemingly not involving the chromosome regions where the fusion gene partners map (18-20).

We here report an AML case carrying a $\mathrm{t}(9 ; 12)(\mathrm{q} 34 ; \mathrm{q} 15)$ chromosomal translocation as the sole cytogenetic anomaly. Using RNA-sequencing, a cryptic $D E K-N U P 214$ (formerly $D E K-C A N$ ) fusion gene as well as a $P R R C 2 B-D E K$ fusion were found.

\section{Materials and Methods}

Ethics statement. The study was approved by the Regional Committee for Medical and Health Research Ethics, South-East Norway (REK Sør-Øst; http://helseforskning.etikkom.no) and written informed consent was obtained from the patient. The ethics committee's approval included a review of the consent procedure. All patient information has been anonymized.

Case report. A 20-year-old male was transferred to our institution with a preliminary diagnosis of AML. He had for two weeks experienced flu-like symptoms with general malaize and strikingly reduced physical stamina. A few days prior to hospitalization, he had also noticed stationary dark spots in his visual field.

Clinical examination was unremarkable. Of note, no gingival hyperplasia was found. There was significant anemia $(6.9 \mathrm{~g} / \mathrm{dl}$ (13.417.0)), thrombocytopenia $\left(26 \times 10^{9} / 1(165-387)\right)$, and leukocytosis (46.3×109/1 (3.6-9.3), monocytes 9.7×109/1 (0.3-0.9)). Elevated LDH $(724 \mathrm{U} / \mathrm{l}(<205))$ and lysozyme $(42 \mathrm{mg} / \mathrm{l}(5-15))$ were also found. A blood smear disclosed numerous blasts and monocytosis. A bone marrow smear revealed a pleomorphic "blastoid" population with cells of variable size, some of which had irregular nuclei with many nucleoli and "dustlike" granules, whereas others had rounded nuclei and abundant blue-grey cytoplasm without granules. Some atypical monocytes and more mature granulocytes with atypical nucleus segmentation were also seen. The blasts displayed the immunophenotype $\mathrm{CD} 34^{+} \mathrm{MPO}^{-} \mathrm{CD} 64^{-/+} \mathrm{CD} 38^{+} \mathrm{CD} 33^{+} \mathrm{CD} 13^{+} \mathrm{HLA}-$ $\mathrm{DR}^{+}$. A diagnosis of acute monoblastic leukemia was made.

Molecular genetic analyses were negative for RUNX1-RUNX1T1, CBFB-MYH11, MLLT-MLL, AFF1-MLL, and MLL-PTD fusion transcripts as well as for NPM1, but FLT3 mutation (TKD) was detected.

Complete hematologic remission was accomplished following induction treatment with daunorubicin and cytarabin. Subsequently, he received two cycles of high dose cytarabine and an allogeneic stem cell transplant from a matched unrelated donor following myeloablative conditioning. At follow up five years post transplantation, he was in complete remission with no signs of graftversus-host disease (GVHD).

G-banding analysis. Bone marrow cells aspirated at diagnosis were cytogenetically investigated $(21,22)$. Chromosome preparations were made from metaphase cells of a 24-h culture, G-banded using Leishman stain, and karyotyped according to ISCN 2016 guidelines (23).

Fluorescence in situ hybridization (FISH). BAC clones were retrieved from the Human " $32 \mathrm{~K}$ " BAC Re-Array library (BACPAC Resources, https://bacpacresources.org/home.htm). They had been selected according to physical and genetic mapping data on chromosomes 6 and 9 (see below) as reported on the Human Genome Browser at the University of California, Santa Cruz website (May 2004, http://genome.ucsc.edu/). FISH mapping of the clones on normal controls was performed to confirm their chromosomal location. For the $D E K$ locus on chromosome 6, the clones were CTD-2300B02 (Position: chr6:18199501-18330748; Band: 6p22.3; UCSC Genome Browser on Human May 2004 NCBI35/hg17 Assembly) and RP11-758007 (Position: chr6:18301067-18524918; Band: 6p22.3); they were labelled red. For the NUP214 locus on chromosome 9, the clones were RP11723C24 (chr9:130882132-131078602; Bands: 9q34.12 - 9q34.13), RP11-68C20 (chr9:131050288-131215735; Band: 9q34.13), and RP11-178K16 (Position: chr9:131131824-131308655; Band: 9q34.13); they were labelled green.

DNA was extracted and probes were labelled and hybridized according to Abbott Molecular recommendations (http://www.abbott molecular.com/home.html). Chromosome preparations were counterstained with $0.2 \mu \mathrm{g} / \mathrm{ml}$ DAPI and overlaid with a $24 \times 50 \mathrm{~mm}^{2}$ coverslip. Fluorescent signals were captured and analyzed using the CytoVision system (Leica Biosystems, Newcastle, UK).

RNA-sequencing. Three $\mu \mathrm{g}$ of total RNA extracted from the patient's bone marrow at the time of diagnosis were sent for high-throughput paired-end RNA-sequencing at the Norwegian Sequencing Centre, Ullevål Hospital (http://www.sequencing.uio.no/). Detailed information about the procedure was given previously (24). The software FusionCatcher was used to discover fusion transcripts (25) (https://github.com/ndaniel/fusioncatcher).

PCR analyses. The procedures of reverse transcriptase-Polymerase Chain Reaction (RT-PCR) and direct sequencing of the PCR products were previously described $(20,24)$. For the amplification of the $D E K$ NUP214 fusion transcript, two primer sets were used: 1) the forward DEK-1060F1 (CACCAAGAAGAATCAAAACAGTTCCA) together with the reverse NUP214-2767R1 (TGAAGACTATCCACCA GGTGATTCAG) and 2) the forward DEK-1060F1 together with NUP214-2709R1 (TGTTGGCTAGGGTGTTAAA CAGTGTC). For amplification of the PRRC2B-DEK fusion transcript, the forward primer PRRC2B-2072-F1 (AGGTGGATGATGATGCCTTCCTAC) together with the reverse primer DEK-1328-R1 (GGGAACGAGTCA TCTTCTCTGTCC) were used.

\section{Results}

The G-banding analysis yielded the karyotype 45,X,$\mathrm{Y}, \mathrm{t}(9 ; 12)(\mathrm{q} 34 ; \mathrm{q} 15)[16]$ (Figure 1).

Using the FusionCatcher software with the fastq files obtained from the Norwegian Sequencing Centre, 9 fusion genes were found (Table I), among them DEK-NUP214 and PRRC2B-DEK. We chose to focus exclusively on these two fusions partly because they were the only ones corresponding to an interchange of material between chromosome bands $9 \mathrm{q} 34$, known to be rearranged by chromosome analysis, and another genomic site, but also because DEK-NUP214 is a known leukemia-specific fusion gene.

PCR and direct sequencing verified the presence of both $D E K-N U P 214$ and PRRC2B-DEK chimeric transcripts 


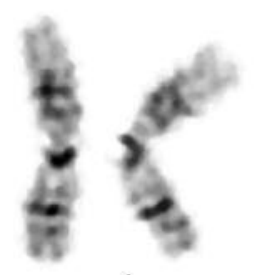

1

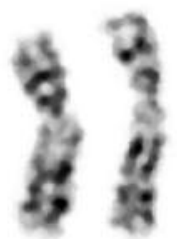

2

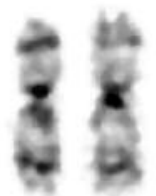

3

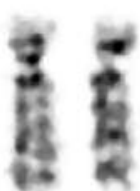

4

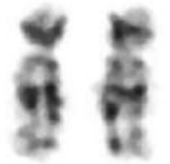

5

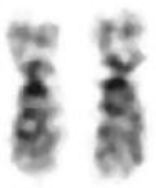

6

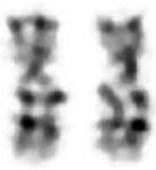

7

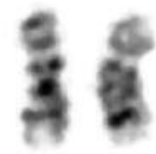

8

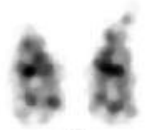

14

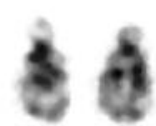

15

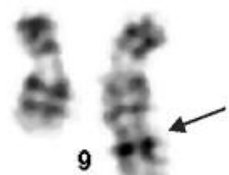

9

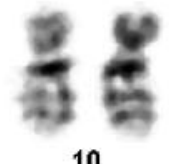

10

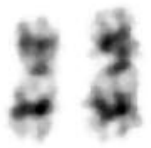

11

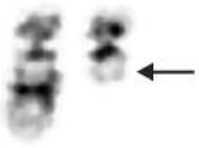

12

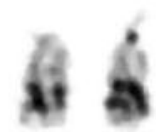

13

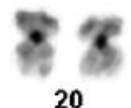

19

20

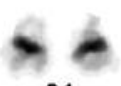

21

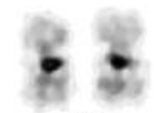

16

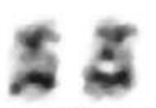

17

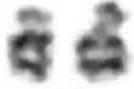

18

Figure 1. G-banding analysis of the bone marrow cells of the AML patient. Karyotype showing the chromosome aberration of leukemic cells: 45,X,-Y,t(9;12)(q34;q15). Arrows indicate breakpoints.

Table I. Fusion genes detected using FusionCatcher.

\begin{tabular}{|c|c|c|c|}
\hline $\begin{array}{l}\text { Gene } 1 \\
\text { (5'-partner) }\end{array}$ & $\begin{array}{c}\text { Gene } 2 \\
\text { (3'-partner) }\end{array}$ & Fusion description & Fusion_sequence \\
\hline$P R R C 2 B$ & $D E K$ & Oncogene & TACCCCTCCGCCCTGCATCCCTCAG*GTCTATGAAAATTATCCTACTTATG \\
\hline AL122127.25 & KIAA0125 & Readthrough & ССССТTСТССCAGGAGGGGAGGCAC*AGCCTGGAGACACAGGCCCСАTCCT \\
\hline$D E K$ & NUP214 & Oncogene & CACAATGAAACAGATTTGCAAAAAG*GAAATTCGGCGCCTTCATCAGTATG \\
\hline CTBS & GNG5 & Readthrough & GCGGGCTCCTTATTATAACTATAAA*GTTTCCCAGGCAGCTGCAGACTTGA \\
\hline DHRS1 & $R A B G G T A$ & Readthrough & GCAAAGGAGGAGGTCCTGCAGGATC*CTCTTGTGGAACGTGCAAAGCCTGT \\
\hline C20ORF197 & MIR646HG & Readthrough & GTGGACTGCAACACCCAGCAGCGCG*AAAGGGACCAGCTTGACGAAGCTTC \\
\hline CRELD1 & PRRT3-AS1 & Readthrough & ATCTGTGTGAAGGAGCAGATCCCAG*TGTGGTTGGCAAGTCATTTAACTTT \\
\hline SMG5 & PAQR6 & Readthrough & AGGGGCTGGCTTTTGGAGTGTTGAG*GTCAACGTGGAGGTACCAGGCCACC \\
\hline POLA2 & $C D C 42 E P 2$ & Readthrough & GTCAGAGCTGAGGTACTTCGTGAAG*CTCCTCAGCCCTGGACCGGGGACAA \\
\hline
\end{tabular}

(Figure 2A-D). In the DEK-NUP214 transcript, exon 9 of $D E K$ (nt 1240 in sequence with accession number NM_003472 version 3) was fused in frame to exon 18 of $N U P 214$ (nt 2581 in NM_005085 version 3) (Figure 2A and B). In the $P R R C 2 B-D E K$ transcript, exon 13 of $P R R C 2 B$ (nt 2162 in sequence with accession number NM_013318 version 3) was fused out of frame to exon 10 of $D E K$ (nt 1241 in NM_003472 version 3) (Figure 2C and D).

FISH on metaphase spreads with probes for DEK (Figure $3 \mathrm{~A}$ and $\mathrm{B}$; red signal) and NUP214 (Figure 3C and D; green 


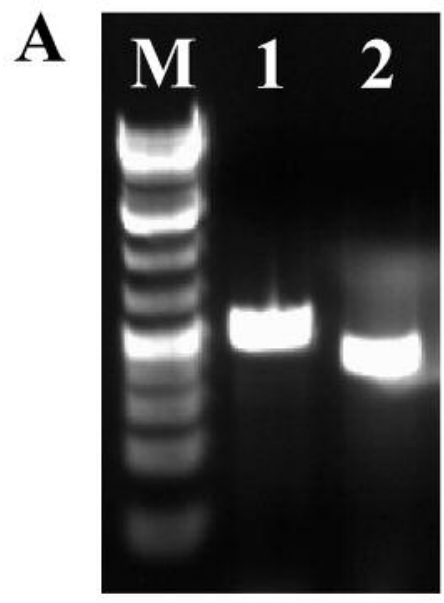

\section{B}
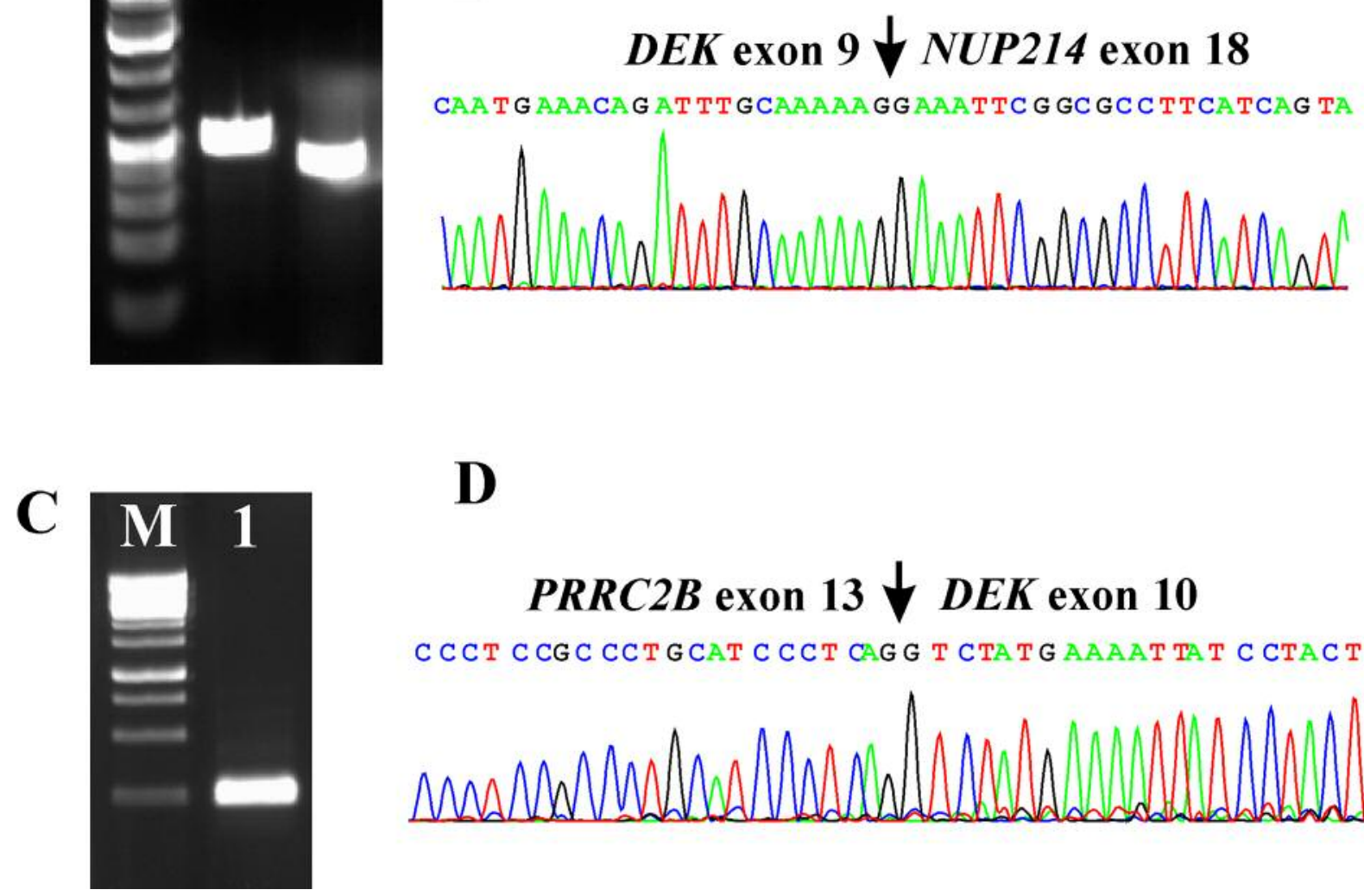

D

\section{$P R R C 2 B$ exon $13 \downarrow D E K$ exon 10 \\ C C CT C CG CCTGCAT C C T CAG T CTATGAAAAT TA T CTACT}

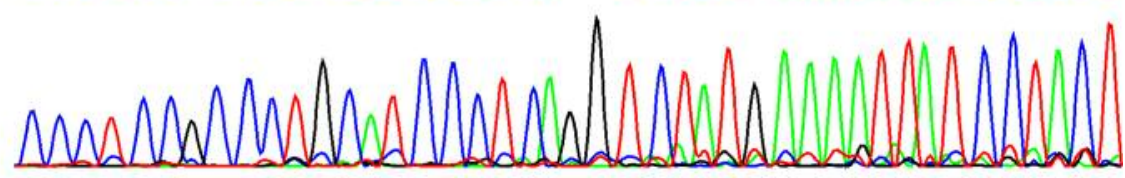

Figure 2. Molecular genetic analysis of bone marrow cells from the AML patient. (A) Gel electrophoresis showing the amplified cDNA DEK-NUP214 fragments using two primer sets. Lane 1, amplification with the primers DEK-1060F1 and NUP214-2767R1. Lane 2, amplification with the primers DEK-1060F1 and NUP214-2709R1. M, 1 Kb DNA ladder (GeneRuler, ThermoFisher). (B) Partial sequence chromatogram of the amplified cDNA fragment showing the junction point of the DEK and NUP214 genes. (C) Gel electrophoresis showing the amplified cDNA PRRC2B-DEK fragment using the primers PRRC2B-2072-F1 and DEK-1328-R1 (lane 1). M, $1 \mathrm{~kb}$ DNA ladder. (D) Partial sequence chromatogram of the amplified cDNA fragment showing the junction point of the PRRC2B and DEK genes.

signal) showed a red signal on one chromosome 6 , two green signals, on the normal chromosome 9 and on the $\operatorname{der}(9)$, and a yellow fusion signal on the other chromosome 6 , although both copies of chromosome 6 appeared cytogenetically normal by G-banding. Thus, FISH showed that the DEK-NUP214 fusion gene was located on the $6 \mathrm{p} 22$ band (Figure $3 \mathrm{E}$ ).

\section{Discussion}

The present case of AML had a $\mathrm{t}(9 ; 12)(\mathrm{q} 34 ; \mathrm{q} 15)$ as the sole aberration at cytogenetic analysis. This translocation was therefore assumed to be a primary leukemogenic rearrangement which might have led to generation of a pathogeneticallyessential fusion gene, and we decided to perform RNAsequencing to find it. We compared karyotyping and sequencing data looking specifically for suggested fusions corresponding to rearrangements between the chromosomal breakpoints, i.e., $9 q 34$ and $12 q 15$. However, none of the 9 fusion genes suggested by the RNA-sequencing data using FusionCather corresponded to the $\mathrm{t}(9 ; 12)(\mathrm{q} 34 ; \mathrm{q} 15)$ (Table I). Instead, the analysis showed generation of DEK-NUP214 and $P R R C 2 B-D E K$ fusion genes and revealed a submicroscopic cytogenetic aberration involving chromosome band $6 \mathrm{p} 22$ (where DEK maps) and 9q34 (where the NUP214 and $P R R C 2 B$ genes map). Subsequently, the presence of both fusion transcripts was confirmed with RT-PCR/direct sequencing methodology. Further FISH investigation showed that both $D E K-N U P 214$ and $P R R C 2 B-D E K$ were generated by insertion of a fragment from $9 \mathrm{q} 34$ into the $6 \mathrm{p} 22$ band of a seemingly normal chromosome 6 (Figure 1). Since all three 
A

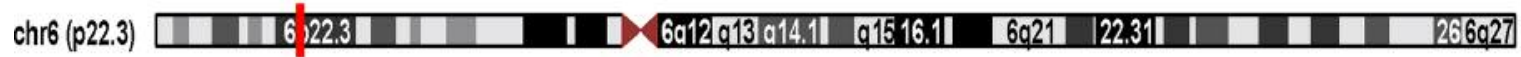

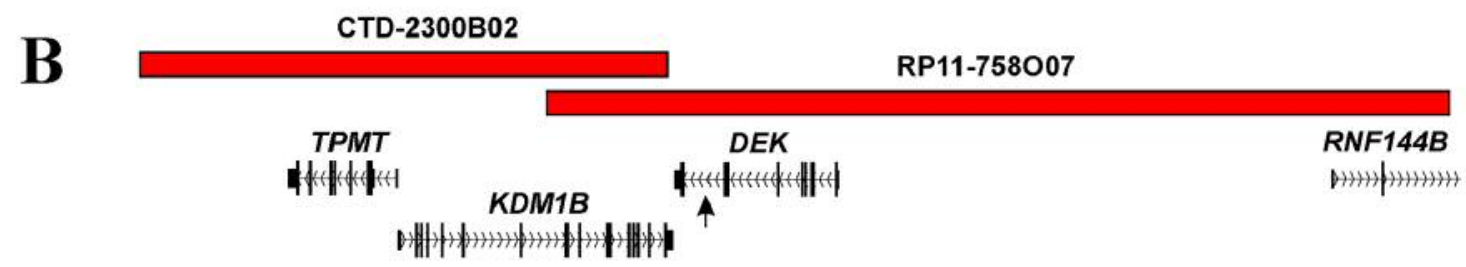

C

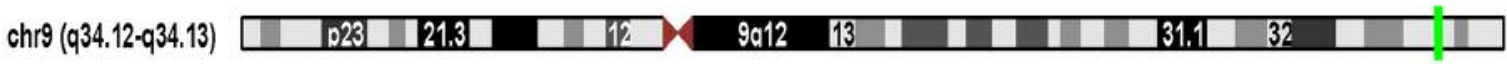

D
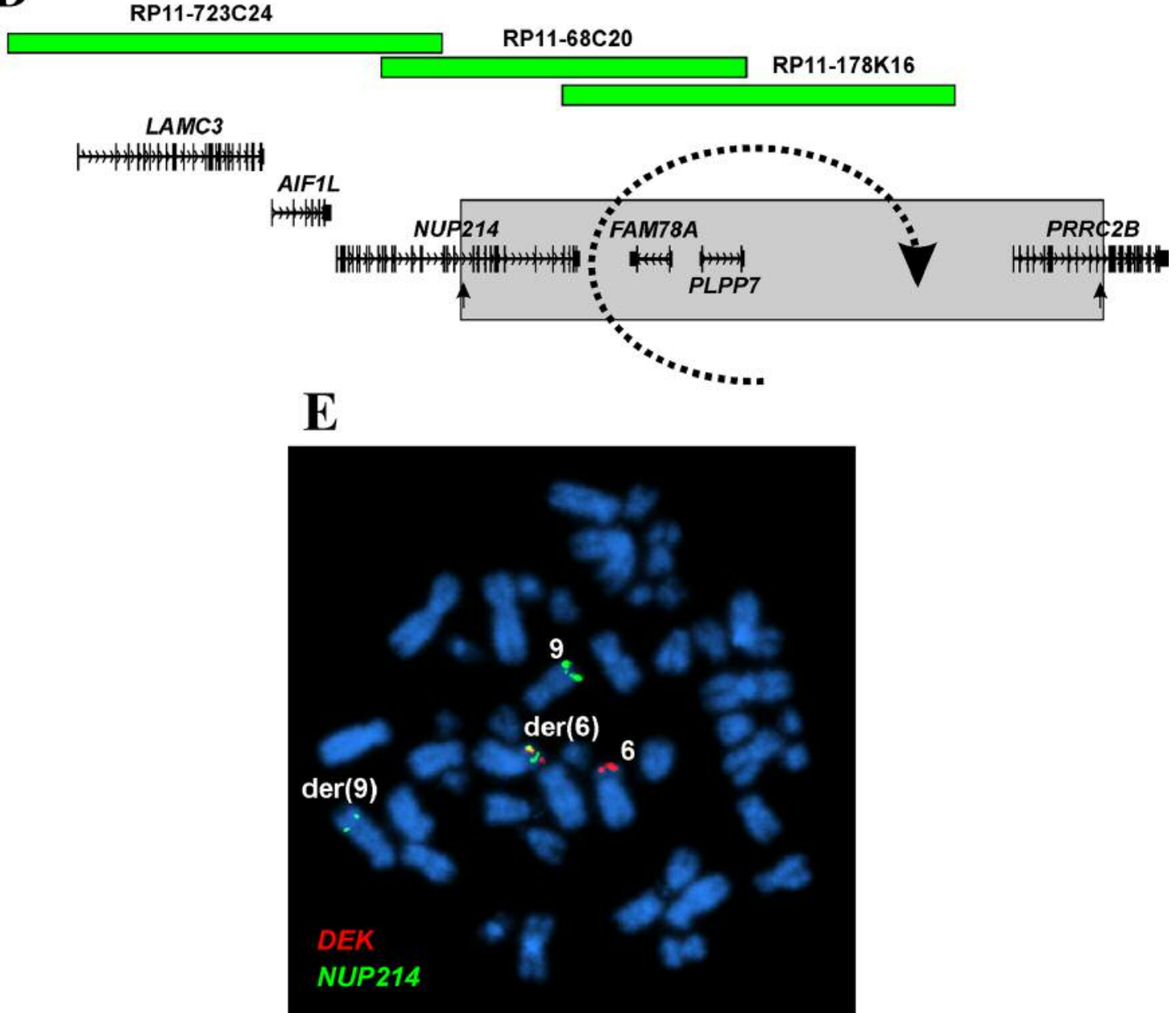

Figure 3. Fluorescence in situ hybridization (FISH) of bone marrow cells from the AML patient. (A) Ideogram of chromosome 6 showing the mapping position of the DEK gene (vertical red line). (B) Diagram showing the FISH probe for DEK. Additional genes in this region are also shown. (C) Ideogram of chromosome 9 showing the mapping position of the NUP214 and PRCC2B genes (vertical green line). (D) Diagram showing the FISH probe for NUP214. Additional genes in this region are also shown. The region between NUP214 and PRCC2B genes which was inverted and inserted in chromosome 6 is marked as grey box. (E) FISH on metaphase with the DEK (red signal) and NUP214 (green signal) probes showing a red signal on chromosome 6, two green signals, one on normal chromosome 9 and one on der(9), and a yellow fusion signal on the second chromosome 6, which was seen as cytogenetically normal. The DEK-NUP214 fusion gene was located on the 6 p22 band. 
genes - DEK, NUP214, and PRRC2B - are transcribed from centromere to telomere, we conclude that the fragment from 9q34 was inverted and inserted into the $D E K$ gene (Figure 3D).

$D E K$-NUP214 is usually the result of a chromosomal translocation, $\mathrm{t}(6 ; 9)(\mathrm{p} 22 ; \mathrm{q} 34)$. It encodes a $165 \mathrm{kDa}$ protein $(26,27)$. The exact role of $D E K-N U P 214$ in leukemogenesis is unknown, but the DEK-NUP214 protein was shown to increase protein synthesis in myeloid cells and the expression of DEK-NUP214 correlates with increased phosphorylation of the translation initiation protein, EIF4E (28). Studies of cell lines carrying a DEK-NUP214 fusion gene have revealed increased cellular proliferation presumably brought about by upregulation of mTOR (29). In addition, DEK-NUP214 induces leukemia in mice (30). The $P R R C 2 B$ gene codes for a 2229 amino acid residue protein. Neither the expression of $P R R C 2 B$ nor the function of its protein product is known (https://www.ncbi.nlm.nih.gov/gene/84726). The gene has no known role in leukemogenesis.

In the 2008 World Health Organization classification, AML with $\mathrm{t}(6 ; 9)(\mathrm{p} 22 ; \mathrm{q} 34) / D E K-N U P 214$ is recognized as a distinct entity (31) corresponding to approximately $1 \%$ of all AMLs. Patients with $\mathrm{t}(6 ; 9)(\mathrm{p} 22 ; \mathrm{q} 34) / D E K-N U P 214$ are often young adults (median age 35 years) or children (median age 13 years). The bone marrow shows distinctive morphologic features, there is a high frequency of FLT3 mutations, the disease is chemotherapy resistant, and the prognosis is very poor (31); however, hematopoietic stem cell transplantation improves the outcome in these patients (32-34). Thus, identification of $\mathrm{t}(6 ; 9)(\mathrm{p} 22 ; \mathrm{q} 34)$ or the DEK-NUP214 fusion gene is crucial in choosing the right treatment. RNAsequencing, as reported here, proved valuable for the detection of a DEK-NUP214 fusion in the leukemic cells whose only cytogenetic clue to being carriers of this leukemogenic change was that they showed rearrangement of chromosomal band $9 \mathrm{q} 34$.

\section{Acknowledgements}

The Authors thank Hege Kilen Andersen and Nina Øino for excellent technical assistance. This study was supported by grants from the Norwegian Radium Hospital Foundation.

\section{References}

1 Heim S and Mitelman F: Cancer Cytogenetics: Chromosomal and Molecular Genetic Abberations of Tumor Cells: WileyBlackwell, Chichester, West Sussex, UK, 2015.

2 Iacobucci I and Mullighan CG: Genetic Basis of Acute Lymphoblastic Leukemia. J Clin Oncol 35: 975-983, 2017.

3 Medinger M and Passweg JR: Acute myeloid leukaemia genomics. Br J Haematol, 2017. doi: 10.1111/bjh.14823. [Epub ahead of print]

4 Papaemmanuil E, Gerstung M, Bullinger L, Gaidzik VI, Paschka P, Roberts ND, Potter NE, Heuser M, Thol F, Bolli N, Gundem G, Van Loo P, Martincorena I, Ganly P, Mudie L, McLaren S,
O'Meara S, Raine K, Jones DR, Teague JW, Butler AP, Greaves MF, Ganser A, Dohner K, Schlenk RF, Dohner H and Campbell PJ: Genomic Classification and Prognosis in Acute Myeloid Leukemia. N Engl J Med 374: 2209-2221, 2016.

5 Bayani J and Squire J: Multi-color FISH techniques. Curr Protoc Cell Biol 24: 22.5.1-22.5.25, 2004.

6 Davies JJ, Wilson IM and Lam WL: Array CGH technologies and their applications to cancer genomes. Chromosome Res 13: 237-248, 2005.

7 Heinrichs S, Li C,and Look AT: SNP array analysis in hematologic malignancies: avoiding false discoveries. Blood 115: 4157-4161, 2010.

8 Mason $\mathbf{J}$ and Griffiths M: Molecular diagnosis of leukemia. Expert Rev Mol Diagn 12: 511-526, 2012.

9 Nordgren A: Hidden aberrations diagnosed by interphase fluorescence in situ hybridisation and spectral karyotyping in childhood acute lymphoblastic leukaemia. Leuk Lymphoma 44: 2039-2053, 2003.

10 Song J and Shao H: SNP Array in Hematopoietic Neoplasms: A Review. Microarrays 5: 1-23, 2015.

11 van der Veken LT and Buijs A: Array CGH in human leukemia: from somatics to genetics. Cytogenet Genome Res 135: 260-270, 2011.

12 Van Loo P, Nilsen G, Nordgard SH, Vollan HK, Borresen-Dale $\mathrm{AL}$, Kristensen $\mathrm{VN}$ and Lingjaerde OC: Analyzing cancer samples with SNP arrays. Methods Mol Biol 802: 57-72, 2012.

13 Golub TR, Barker GF, Bohlander SK, Hiebert SW, Ward DC, Bray-Ward P, Morgan E, Raimondi SC, Rowley JD and Gilliland DG: Fusion of the TEL gene on 12p13 to the AML1 gene on 21q22 in acute lymphoblastic leukemia. Proc Natl Acad Sci USA 92: 4917-4921, 1995.

14 Shurtleff SA, Buijs A, Behm FG, Rubnitz JE, Raimondi SC, Hancock ML, Chan GC, Pui CH, Grosveld G and Downing JR: TEL/AML1 fusion resulting from a cryptic $t(12 ; 21)$ is the most common genetic lesion in pediatric ALL and defines a subgroup of patients with an excellent prognosis. Leukemia 9: 1985-1989, 1995.

15 Cools J, DeAngelo DJ, Gotlib J, Stover EH, Legare RD, Cortes J, Kutok J, Clark J, Galinsky I, Griffin JD, Cross NC, Tefferi A, Malone J, Alam R, Schrier SL, Schmid J, Rose M, Vandenberghe P, Verhoef G, Boogaerts M, Wlodarska I, Kantarjian H, Marynen P, Coutre SE, Stone R and Gilliland DG: A tyrosine kinase created by fusion of the PDGFRA and FIP1L1 genes as a therapeutic target of imatinib in idiopathic hypereosinophilic syndrome. N Engl J Med 348: 1201-1214, 2003.

16 Gotlib J and Cools J: Five years since the discovery of FIP1L1PDGFRA: what we have learned about the fusion and other molecularly defined eosinophilias. Leukemia 22: 1999-2010, 2008.

17 Curtis C and Ogbogu P: Hypereosinophilic Syndrome. Clin Rev Allergy Immunol 50: 240-251, 2016.

18 Welch JS, Westervelt P, Ding L, Larson DE, Klco JM, Kulkarni S, Wallis J, Chen K, Payton JE, Fulton RS, Veizer J, Schmidt H, Vickery TL, Heath S, Watson MA, Tomasson MH, Link DC, Graubert TA, DiPersio JF, Mardis ER, Ley TJ and Wilson RK: Use of whole-genome sequencing to diagnose a cryptic fusion oncogene. JAMA 305: 1577-1584, 2011.

19 Gruber TA, Larson Gedman A, Zhang J, Koss CS, Marada S, Ta HQ, Chen SC, Su X, Ogden SK, Dang J, Wu G, Gupta V, Andersson AK, Pounds S, Shi L, Easton J, Barbato MI, Mulder HL, Manne J, Wang J, Rusch M, Ranade S, Ganti R, Parker M, 
Ma J, Radtke I, Ding L, Cazzaniga G, Biondi A, Kornblau SM, Ravandi F, Kantarjian H, Nimer SD, Dohner K, Dohner H, Ley TJ, Ballerini P, Shurtleff S, Tomizawa D, Adachi S, Hayashi Y, Tawa A, Shih LY, Liang DC, Rubnitz JE, Pui CH, Mardis ER, Wilson RK and Downing JR: An Inv(16)(p13.3q24.3)-encoded CBFA2T3-GLIS2 fusion protein defines an aggressive subtype of pediatric acute megakaryoblastic leukemia. Cancer Cell 22: 683-697, 2012.

20 Panagopoulos I, Gorunova L, Zeller B, Tierens A and Heim S: Cryptic FUS-ERG fusion identified by RNA-sequencing in childhood acute myeloid leukemia. Oncol Rep 30: 2587-2592, 2013.

21 Czepulkowski B: Basic techniques for the preparation and analysis of chromosomes from bone marrow and leukaemic blood. In: Human cytogenetics: malignancy and acquired abnormalities (Rooney DE ed.). New York: Oxford University Press, pp. 1-26, 2001.

22 Potter AM and Watmore A: Cytogenetics in myeloid leukaemia. In: Human cytogenetics: malignancy and acquired abnormalities (Rooney DE ed.). New York: Oxford University Press, pp. 27$55,2001$.

23 McGowan-Jordan J, Simons A and Schmid M: ISCN 2016: An International System for Human Cytogenomic Nomenclature. Basel: Karger, 2016.

24 Panagopoulos I, Torkildsen S, Gorunova L, Tierens A, Tjonnfjord GE and Heim S: Comparison between karyotypingFISH-reverse transcription PCR and RNA-sequencing-fusion gene identification programs in the detection of KAT6ACREBBP in acute myeloid leukemia. PLoS One 9: e96570, 2014.

25 Nicorici D, Satalan H, Edgren H, Kangaspeska S, Murumagi A, Kallioniemi O, Virtanen S and Kikku O: FusionCatcher - a tool for finding somatic fusion genes in paired-end RNA-sequencing data. BioRxiv, 2014. doi: https://doi.org/10.1101/011650. [Epub ahead of print]

26 von Lindern M, Poustka A, Lerach H and Grosveld G: The (6;9) chromosome translocation, associated with a specific subtype of acute nonlymphocytic leukemia, leads to aberrant transcription of a target gene on 9q34. Mol Cell Biol 10: 4016-4026, 1990.

27 von Lindern M, Fornerod M, van Baal S, Jaegle M, de Wit T, Buijs A, and Grosveld G: The translocation (6;9), associated with a specific subtype of acute myeloid leukemia, results in the fusion of two genes, dek and can, and the expression of a chimeric, leukemia-specific dek-can mRNA. Mol Cell Biol 12: 1687-1697, 1992.

28 Ageberg M, Drott K, Olofsson T, Gullberg U and Lindmark A: Identification of a novel and myeloid specific role of the leukemia-associated fusion protein DEK-NUP214 leading to increased protein synthesis. Genes Chromosomes Cancer 47: 276-287, 2008.
29 Sandén C, Ageberg M, Petersson J, Lennartsson A and Gullberg $\mathrm{U}$ : Forced expression of the DEK-NUP214 fusion protein promotes proliferation dependent on up-regulation of mTOR. BMC Cancer 13: 440, 2013.

30 Oancea C, Ruster B, Henschler R, Puccetti E and Ruthardt M: The $t(6 ; 9)$ associated DEK/CAN fusion protein targets a population of long-term repopulating hematopoietic stem cells for leukemogenic transformation. Leukemia 24: 1910-1919, 2010.

31 Arber DA, Brunning RD, Le Beau MM, Vardiman JW, Porwit JW, Thiele J and Bloomfield CD: Acute myeloid leukaemia with recurrent genetic abnormalities $I n$ : WHO classification of tumours of haematopoietic and lymphoid tissues (Swerdlow SH, Campo E, Harris NL, Jaffe ES, Pileri SA, Stein H, Thiele J, Vardiman JW eds.). Lyon, France: International Agency for Research on Cancer (IARC), pp. 110-123, 2008.

32 Esteve J, Labopin M, Socie G, Ljungman PT, Maertens J, Schattenberg A, Maury S, Jouet JP, Polge E, Rocha V and Mohty M: Allogeneic Hematopoietic Stem-Cell Transplantation In Early Phase Might Overcome the Adverse Prognosis of Acute Myeloid Leukemia with Translocation $\mathrm{t}(6 ; 9)(\mathrm{p} 23 ; \mathrm{q} 34) / \mathrm{DEK}-\mathrm{NP} 214(\mathrm{CAN})$ Rearrangement. A Retrospective Analysis From the Acute Leukemia Working Party of EBMT. Blood 116: 1438-1438, 2010.

33 Ishiyama K, Takami A, Kanda Y, Nakao S, Hidaka M, Maeda T, Naoe T, Taniguchi S, Kawa K, Nagamura T, Atsuta Y and Sakamaki H: Allogeneic hematopoietic stem cell transplantation for acute myeloid leukemia with $\mathrm{t}(6 ; 9)(\mathrm{p} 23 ; \mathrm{q} 34)$ dramatically improves the patient prognosis: a matched-pair analysis. Leukemia 26: 461-464, 2012.

34 Sandahl JD, Coenen EA, Forestier E, Harbott J, Johansson B, Kerndrup G, Adachi S, Auvrignon A, Beverloo HB, Cayuela JM, Chilton L, Fornerod M, de Haas V, Harrison CJ, Inaba H, Kaspers GJ, Liang DC, Locatelli F, Masetti R, Perot C, Raimondi SC, Reinhardt K, Tomizawa D, von Neuhoff N, Zecca M, Zwaan CM, van den Heuvel-Eibrink MM and Hasle H: $\mathrm{t}(6 ; 9)(\mathrm{p} 22 ; \mathrm{q} 34) / D E K-N U P 214-$ rearranged pediatric myeloid leukemia: an international study of 62 patients. Haematologica 99: 865-872, 2014.
Received September 7, 2017

Revised October 6, 2017

Accepted October 12, 2017 